ENTREPRENEURSHIP AND SUSTAINABILITY ISSUES

ISSN 2345-0282 (online) http://jssidoi.org/jesi/ 2019 Volume 7 Number 1 (September)

http://doi.org/10.9770/jesi.2019.7.1(44)

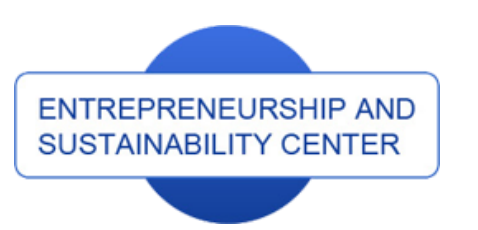

Publisher

http://jssidoi.org/esc/home

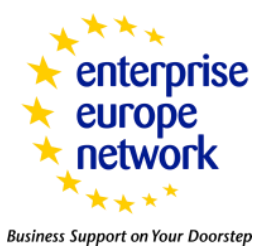

CASPA

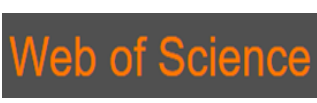

Clarivate
Analytics

\title{
REGIONAL ASPECTS OF THE DEVELOPMENT OF THE CHEESE MARKET IN TERMS OF THE TREND OF HEALTHY NUTRITION
}

\author{
Leonid Aleksandrovich Bragin', Svetlana Victorovna Panasenko², Alexander Fedorovich Nikishin ${ }^{3}$, \\ Svetlana Borisovna Aleksina ${ }^{4}$, Anastasiya Vladimirovna Boykova ${ }^{5}$ \\ ${ }^{1-5}$ Plekhanov Russian University of Economics, 36 Stremyanny Per, 117997, Moscow, Russia \\ E-mail: ${ }^{1}$ Bragin.LA@rea.ru ; ${ }^{2}$ Panasenko.SV@rea.ru ; ${ }^{3}$ Nikishin.AF@rea.ru ; ${ }^{4}$ Aleksina.SB@rea.ru ; \\ 5boykovaanastasiya@yandex.ru
}

Received 18 March 2019; accepted 6 August 2019; published 30 September

\begin{abstract}
In public nutrition nowadays, the trend of healthy nutrition is gaining momentum. One of the products that can be attributed to this category is cheese. In modern conditions, the consumption of cheese by the population of the country is characterized by high regional differentiation. An analysis of the cheese market and the main factors of its development in the context of the trend of healthy nutrition served as the purpose of this study. The information base of research is the consumption of cheese by the population of the Russian Federation (a case study of the 16 largest regions of the country). Particular attention is paid to the analysis of the cream cheese market, which currently has a low share in the sales structure of this group of goods, but has a high potential for consumption growth. As a result of the analysis, it has been revealed that the greatest influence on the consumption of cream cheese is exerted by such factors as the number of sales outlets per capita in the region, the number of assortment positions in the store, and the level of trade integration.
\end{abstract}

Keywords: healthy food; regional trade; cheese market; cream cheese; development of the cheese market

Reference to this paper should be made as follows: Bragin, L.A.; Panasenko, S.V.; Nikishin, A.F.; Aleksina, S.B.; Anastasiya Boykova, V. 2019. Regional aspects of the development of the cheese market in terms of the trend of healthy nutrition, Entrepreneurship and Sustainability Issues 7(1): 626-636. http://doi.org/10.9770/jesi.2019.7.1(44)

JEL Classifications: Q13

\section{Introduction}

One of the current trends in the development of modern lifestyle is the promotion of healthy nutrition. A huge role in the development of this trend is played by the trade, directly providing services to end users. An important aspect of the development of healthy nutrition as a function of improving the quality of people's life is the assortment policy of trade organizations. Ivanov (2014) shows the influence of the quality of the goods sold on improving business reputation, and, consequently, increasing the social efficiency of trade in general. The sale of healthy food products is not limited to the economic benefits of the manufacturer and the seller, but, together, plays an important social role (Kornilova \& Karashchuk, 2017). 


\section{ENTREPRENEURSHIP AND SUSTAINABILITY ISSUES}

ISSN 2345-0282 (online) http://jssidoi.org/jesi/ 2019 Volume 7 Number 1 (September) http://doi.org/10.9770/jesi.2019.7.1(44)

The period from the mid-20th century to the present is characterized by a strong anthropogenic load on the environment, which has led to a decrease in the level of safety and quality of food products (Eliseeva et al., 2015), and a healthy diet, in the first place, implies safe food products. One of the categories of products that characterize the trend of healthy nutrition is dairy products (Malaws \& McDonald, 2018). It should be noted that a feature of dairy products is relatively short shelf life, and, accordingly, a short sale period. In modern conditions, the majority of commodity producers use various methods to increase the above time, which is often negatively perceived by the consumers, in terms of the trend of healthy nutrition. It should be noted that in a number of countries, the sale of raw cow milk for human consumption is prohibited due to regulatory requirements. In this regard, farmers are forced to seek various ways to sell their products (Linn, 2019). Also, a big role in the development of the making of various milk processing products is played by the change of the real prices of raw milk (Santos-Lavalle, 2018).

One of the dairy products, initially having sufficient shelf life to be sold, is cheeses. Canfora (2018) shows the perception of cheese by a number of consumers as an element of healthy nutrition. This category of goods can be sold by commodity producers either through the system of federal and regional distributors or through direct deliveries to the network retail system. Thus, the organization of sales of cheese is an important direction in the functioning of an effective distribution system in the FMCG market (Aleksina, 2018-19). Filipovic (2019) showed the high role of proper cheese distribution in forming consumer preferences.

In works by Buleca (Buleca et al., 2018), it is shown that as a result of the abolition of the quota system, the low price of raw cow milk has significant impact on the processes of production concentration. Ito (2019) revealed the important role of regional factors in forming consumer preferences. Zindy (2017) also showed the high role of the region of cheese production in forming consumer preferences.

Nigri (2014) discusses the benefits of cheese production by local producers. In particular, that paper noted that local production has impact on the environment. This study also allows concluding that there is a high potential for the sale of locally produced cheese. In turn, the innovations in the technological chain of cheese production currently lead to the formation of a wider range of cheese products (Quaranta \& Salvia, 2017).

In the conditions of development of a digital economy, the consumers more carefully approach the formation of their choice by studying the properties of a product, reviews about it, which, in the context of the healthy nutrition trend, leads to the formation of a choice of higher-quality cheeses and a decrease in demand for products containing vegetable oils, unsafe components and those undesirable from the point of view of healthy nutrition. The importance of developing the interaction of various parts of regional distribution in the conditions of increasing the social responsibility of trade is shown in works by Mayorova (2018), which also determines the relevance of the study of regional aspects of the sale of healthy food products. A number of researchers currently note the importance of replacing traditional food products with products of their industrial processing (Honfoga et al., 2018). In particular, De-Magistris (2016) has shown that consumers are willing to pay a price premium for a pack of low-fat cheese or low-fat and low-salt cheese appearing together; however, they are not willing to pay for a pack of low-salt cheese. Also, the consumers' trend of healthy nutrition is analyzed by Sanchez-Macias (2012) taking the goat cheese market as a case study.

In works by Boatto (Boatto et al., 2016), the high role of personal preferences and price factors in the sale of cheese is shown.

As problems in the sale of various types of cheese products, it is advisable to note the insufficiently high level of safety of existing production facilities. In this regard, manufacturers need to intensify the use of all necessary measures in order to prevent food contamination (Angelidis et al., 2012). The importance of an environmental approach in the production of cheese is also discussed in research of Ceccarelli (Ceccarelli, 2017). 
Thus, the study of trends in the development of the market for healthy food products, in particular, the cheese market, is relevant. The purpose of this study is to analyze the cheese market in the context of the trend of healthy nutrition, as well as to identify the main factors of its development. In particular, an important aspect is the analysis of the market for cream cheeses, which do not have a significant market share today, but have prospects for increasing this share.

\section{Methods}

As the information base for this study, cheese consumption in a number of regions of the Russian Federation was chosen, as a state with a rather large level of differentiation of both the standard of living and the culture of cheese consumption in the regional context.

The sample size of the study was 16 largest regions, covering more than $50 \%$ of the population. In conducting the study, the priority was to consider the consumption of cheese by the urban population, since it is precisely this category of the population that faces the problem of maintaining a healthy lifestyle. It should be noted that the nature of consumption in large cities quite accurately corresponds to the nature of consumption in the whole country, the correlation coefficient being 0.9 .

In recent years, the Russian cheese market has undergone major volumetric and structural changes due to a whole range of economic and socio-political reasons. As a result of the dramatic change in the structure of imports of these products to Russia at the end of 2014, there was a significant shift in the dynamics of the cheese market. As can be seen from Table 1, the segment of the market of hard and semi-hard cheeses suffered most from the crisis, the trend for the decline in sales volumes of which was observed during 2014-2017.

Table 1. Dynamics of sales of cheese in the Russian Federation in physical terms, growth rate, $\%$

\begin{tabular}{|l|c|c|c|c|c|c|}
\hline \multirow{2}{*}{ Cheese market segments } & \multicolumn{5}{|c|}{ Years } \\
\cline { 2 - 7 } & $2014 / 2013$ & $2015 / 2014$ & $2016 / 2015$ & $2017 / 2016$ & $2018 / 2017$ & $2018 / 2013$ \\
\hline Hard/Semi-hard cheese & 92.76 & 89.19 & 97.64 & 98.62 & 100.35 & 79.94 \\
\hline Processed cheese & 104.76 & 104.08 & 99.55 & 97.85 & 100.64 & 106.89 \\
\hline Cream cheese & 103.65 & 102.82 & 109.59 & 109.38 & 106.29 & 135.77 \\
\hline Feta/Brynza & 91.79 & 91.58 & 106.90 & 107.53 & 101.50 & 98.07 \\
\hline Mozzarella & 94.92 & 110.71 & 106.45 & 98.48 & 103.08 & 113.56 \\
\hline Other & 101.84 & 94.95 & 92.40 & 90.12 & 100.00 & 80.51 \\
\hline TOTAL & 95.84 & 93.49 & 98.73 & 98.50 & 100.87 & 87.90 \\
\hline
\end{tabular}

Source: Compiled by the authors according to research company Nielsen

Over the past 4 years, cheese consumption in the Russian Federation has decreased, and only in the last year, there has been a stabilization trend. In particular, in 2018, the consumption of cheese in Russia amounted to $87.9 \%$ of the 2013 level. It should be noted that a sharp change in the structure of imports of cheese has a great effect. However, this trend is positive for a number of cheeses. In particular, sales of cream cheese in 2018 amounted to $135.8 \%$ of the 2013 level. This trend is sustainable; over the past 5 years, the minimum annual growth rate was $2.8 \%$, the maximum $-9 \%$. For this type of cheese, growth rates are maximum, which determines the prospects for the sales of cream cheese. This is largely consistent with the trend conditions for healthy nutrition. 
As noted above, for the purpose of analysis, the authors selected 16 largest regions of the Russian Federation, with a population exceeding 1 million people. The study analyzed the development of the cheese market, as fully consistent with the analyzed trend for healthy nutrition and demonstrating the highest growth potential. The main factors of influence chosen were such as the number of places of sale of cream cheese per capita, the numerical distribution, the number of SKU (stock keeping units) in the stores, the provision of population with modern shopping formats per 1,000 people, the share of sales via the Internet, the share of turnover of retail chains in the sale of goods, the retail trade per capita, the percentage of male and urban population in the region, the average per capita cash income of the population.

For the purpose of analysis, the calculation of the correlation coefficient was used, and the relationship between real and calculated values was used to estimate nonlinear dependencies.

\section{Results}

Currently, it is the market segment of cream cheese that shows the steadiest upward trend. As shown in Table 2, over the past 5 years, there has been an increase in the share of cream cheese in total sales (in physical terms) by one and a half times, from 2.59 to $4 \%$.

Table 2. Structure of retail sales of cheese in the Russian Federation in physical terms in 2013 and 2018

\begin{tabular}{|l|c|c|c|}
\hline \multirow{2}{*}{ Cheese market segments } & \multicolumn{2}{|c|}{ Share in sales volume, \% } & \multirow{2}{*}{ Change in sales share } \\
\cline { 2 - 4 } & 2013 & 2018 & -6.03 \\
\hline Hard/Semi-hard cheese & 67.80 & 61.77 & 4.25 \\
\hline Processed cheese & 19.45 & 23.70 & 0.46 \\
\hline Cream cheese & 3.91 & 4.37 & 1.41 \\
\hline Feta/Brynza & 2.59 & 4.00 & 0.33 \\
\hline Mozzarella & 1.11 & 1.44 & -0.43 \\
\hline Other & 5.14 & 4.71 & - \\
\hline TOTAL & 100 & 100 & \\
\hline
\end{tabular}

Source: Compiled by the authors according to research company Nielsen

As can be seen from Table 2, despite the insignificant share of cream cheese in the sales structure, the share of cream and processed cheese is currently increasing, while the share of hard and semi-hard cheeses, which constitute a large part of the market, is decreasing.

Table 3 shows the results of the analysis of the main factors that influence the sales of cream cheese.

Table 3. Analysis of the influence of a number of factors on the sales of cream cheese in the Russian Federation in 2016-2018

\begin{tabular}{|c|l|c|c|}
\hline \multirow{2}{*}{ No. } & \multicolumn{1}{|c|}{ Factor } & \multicolumn{2}{|c|}{ Correlation coefficient } \\
\cline { 3 - 4 } & & $\begin{array}{c}\text { Sales of cream cheese per } \\
\text { capita in the region in } \\
\text { physical terms }\end{array}$ & $\begin{array}{c}\text { Share of cream cheese sales } \\
\text { in the total retail turnover of } \\
\text { the region }\end{array}$ \\
\hline 1 & $\begin{array}{l}\text { Number of places of cream cheese sale per } \\
\text { capita in the region }\end{array}$ & 0.68 & 0.82 \\
\hline 2 & Numerical distribution in the region & 0.53 & 0.36 \\
\hline 3 & $\begin{array}{l}\text { Number of assortment positions (SKU) in the } \\
\text { stores of the region }\end{array}$ & 0.76 & 0.71 \\
\hline 4 & $\begin{array}{l}\text { Provision of the population with modern format } \\
\text { shopping areas in the region }\end{array}$ & 0.54 & 0.45 \\
\hline 5 & Share of online sales in the region & 0.38 & 0.47 \\
\hline 6 & $\begin{array}{l}\text { Share of retail trade turnover in the sale of } \\
\text { goods in the region }\end{array}$ & 0.77 & 0.84 \\
\hline
\end{tabular}


ENTREPRENEURSHIP AND SUSTAINABILITY ISSUES

ISSN 2345-0282 (online) http://jssidoi.org/jesi/ 2019 Volume 7 Number 1 (September) http://doi.org/10.9770/jesi.2019.7.1(44)

\begin{tabular}{|c|l|c|c|}
\hline \multirow{2}{*}{ No. } & \multicolumn{1}{|c|}{ Factor } & \multicolumn{2}{|c|}{ Correlation coefficient } \\
\cline { 3 - 4 } & & $\begin{array}{c}\text { Sales of cream cheese per } \\
\text { capita in the region in } \\
\text { physical terms }\end{array}$ & $\begin{array}{c}\text { Share of cream cheese sales } \\
\text { in the total retail turnover of } \\
\text { the region }\end{array}$ \\
\hline 7 & Retail trade turnover per capita in the region & 0.43 & 0.12 \\
\hline 8 & Share of the male population in the region & -0.25 & -0.18 \\
\hline 9 & Share of the urban population in the region & 0.64 & 0.60 \\
\hline 10 & Per capita income in the region & 0.55 & 0.27 \\
\hline
\end{tabular}

Source: Compiled by the authors

As can be seen from Table 3, the sale of cream cheese in the regions of the Russian Federation is influenced by factors directly related to the presence of retail organizations, in particular, the number of places for the sale of cream cheese per capita, as well as the share of retail chains turnover in the sale of goods. Also, SKU is important (stock keeping units, or the number of positions) in the stores. Some influence is exerted by the proportion of the urban population in the region. The absence of a significant dependency of the share of sales of cream cheese in the total retail trade turnover on the average per capita income of the population is also of interest.

Table 4 shows an analysis of the nature of the dependency between the share of cream cheese sales in the total retail trade turnover and a number of factors.

Table 4. Analysis of the influence of a number of factors on the sales of cream cheese in the Russian Federation in 2016-2018

\begin{tabular}{|c|l|c|c|}
\hline \multirow{2}{*}{ No. } & \multicolumn{1}{|c|}{ Factor } & \multicolumn{2}{|c|}{ Nature of dependency } \\
\cline { 3 - 4 } & & \multicolumn{1}{|c|}{ Linear } & 0.83 \\
\hline 1 & $\begin{array}{l}\text { Number of places of cream cheese sale per } \\
\text { capita in the region }\end{array}$ & 0.82 & 0.36 \\
\hline 2 & Numerical distribution in the region & 0.36 & 0.79 \\
\hline 3 & $\begin{array}{l}\text { Number of assortment positions (SKU) in the } \\
\text { stores of the region }\end{array}$ & 0.71 & 0.59 \\
\hline 4 & $\begin{array}{l}\text { Provision of the population with modern format } \\
\text { shopping areas in the region }\end{array}$ & 0.45 & 0.47 \\
\hline 5 & Share of online sales in the region & 0.47 & 0.88 \\
\hline 6 & $\begin{array}{l}\text { Share of retail trade turnover in the sale of } \\
\text { goods in the region }\end{array}$ & 0.84 & 0.16 \\
\hline 7 & Retail trade turnover per capita in the region & 0.12 & -0.24 \\
\hline 8 & Share of the male population in the region & -0.18 & 0.63 \\
\hline 10 & Share of the urban population in the region & 0.60 & 0.27 \\
\hline
\end{tabular}

Source: Compiled by the authors

As can be seen from Table 4, for a number of factors, the nonlinear nature of the dependency can be noted. A general view of the dependency of the share of cream cheese sales in the total retail turnover on such factors as SKU in the region's stores and the share of retail trade turnover in the sale of goods in the region is shown in Figure 1. 


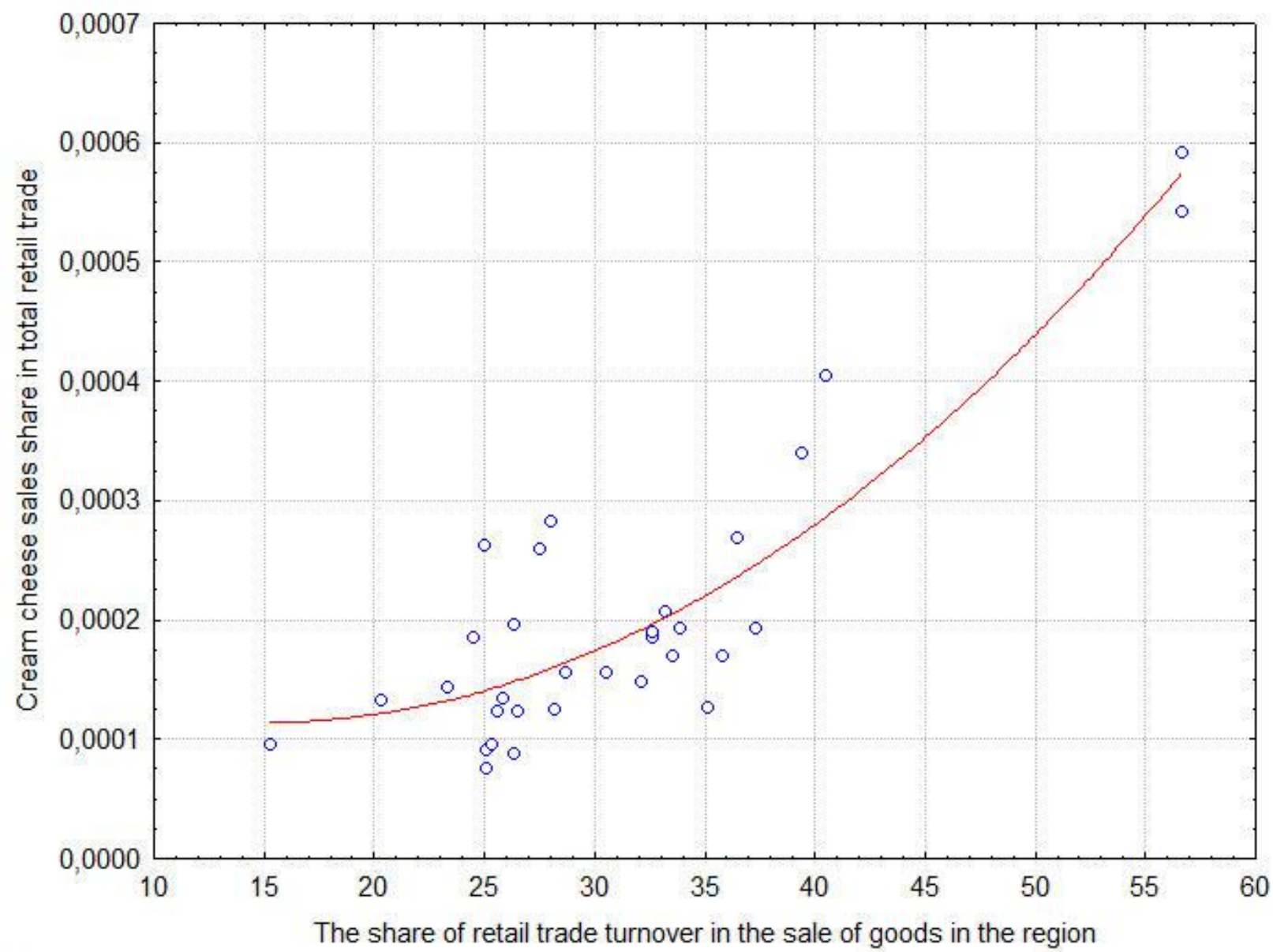

Fig. 1. Dependency of the share of sales of cream cheese in the total retail turnover on the share of the turnover of retail chains in the sale of goods

Source: Compiled by the authors

As shown in Fig. 1, the dependency of the share of sales of cream cheese in the total retail trade turnover on the share of retail trade turnover in the sale of goods in the region is high and is also characterized by outstripping growth rates.

Of interest is the comparison of the sales of cream cheese with other types of cheeses. In particular, as was shown earlier, a segment of processed cheese also has great development potential. In particular, Talbot-Walsh (2018) showed that processed cheeses with enhanced health benefits were of great interest to producers and consumers. Fig. 2 shows the relationship of the sale of processed and cream cheeses. 


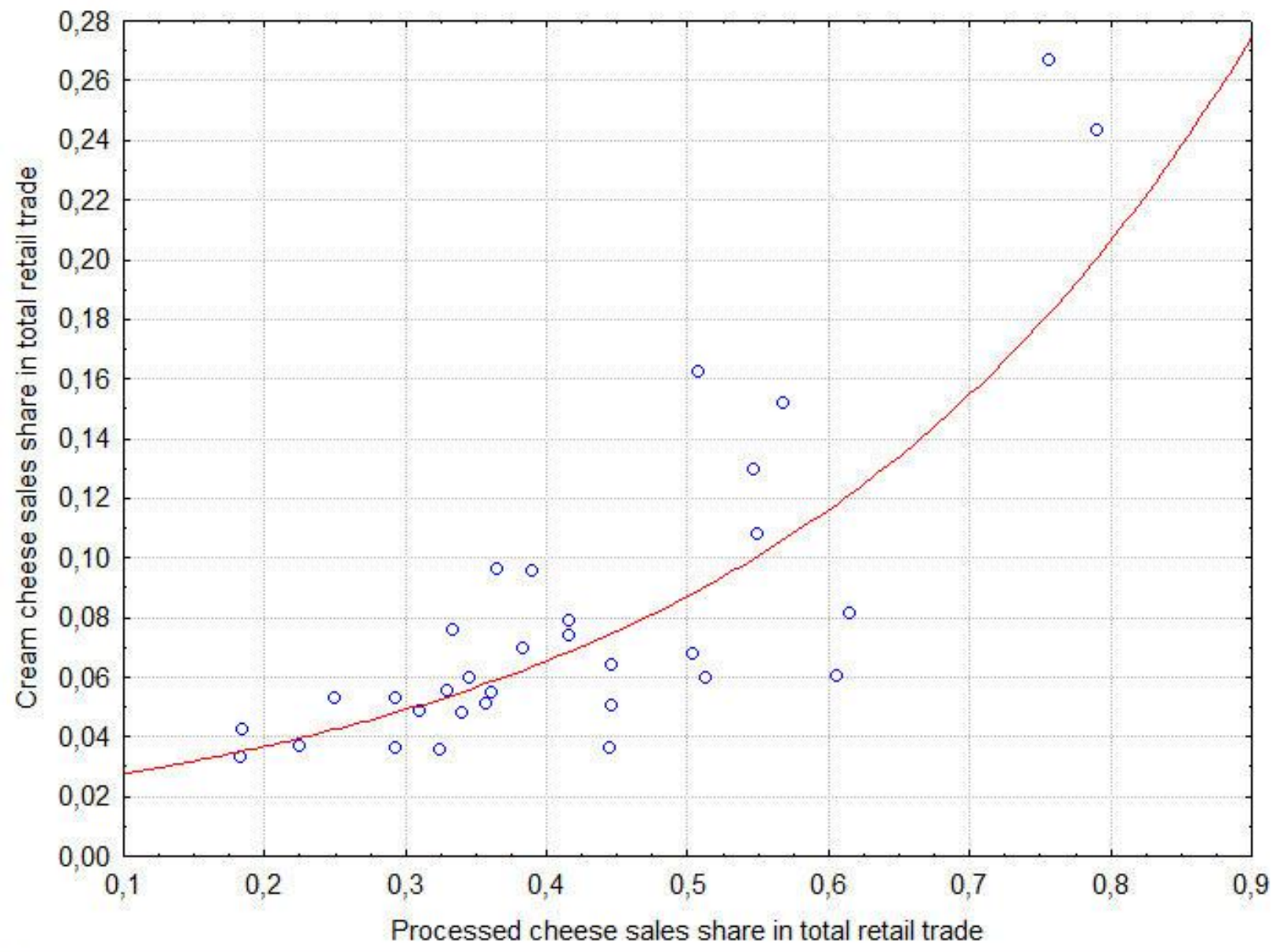

Fig. 2. Relationship of the sale of processed and cream cheese Source: Compiled by the authors

The correlation coefficient between the sale of cream and processed cheese is 0.79 . Moreover, as can be seen in Fig. 2, there has been an outstripping growth rate of sales of cream cheese compared to processed cheese.

Table 5 shows the impact of a number of factors on the sales of cream and processed cheese in the Russian Federation in 2016-2018.

Table 5. Analysis of the influence of a number of factors on the sales of cream and processed cheese in the Russian Federation in 20162018

\begin{tabular}{|c|l|c|c|}
\hline \multirow{2}{*}{ No. } & \multicolumn{1}{|c|}{ Factor } & \multicolumn{2}{|c|}{ Correlation coefficient } \\
\cline { 3 - 4 } & & Cream cheese & Processed cheese \\
\hline 1 & $\begin{array}{l}\text { Number of places of cream cheese sale per } \\
\text { capita in the region }\end{array}$ & 0.82 & 0.72 \\
\hline 2 & Numerical distribution in the region & 0.36 & -0.05 \\
\hline 3 & $\begin{array}{l}\text { Number of assortment positions (SKU) in the } \\
\text { stores of the region }\end{array}$ & 0.71 & 0.27 \\
\hline 4 & $\begin{array}{l}\text { Provision of the population with modern format } \\
\text { shopping areas in the region }\end{array}$ & 0.45 & 0.38 \\
\hline 5 & Share of online sales in the region & 0.47 & 0.55 \\
\hline 6 & Share of retail trade turnover in the sale of & 0.84 & 0.82 \\
\hline
\end{tabular}


ENTREPRENEURSHIP AND SUSTAINABILITY ISSUES

ISSN 2345-0282 (online) http://jssidoi.org/jesi/ 2019 Volume 7 Number 1 (September) http://doi.org/10.9770/jesi.2019.7.1(44)

\begin{tabular}{|c|l|c|c|}
\hline \multirow{2}{*}{ No. } & \multicolumn{1}{|c|}{ Factor } & \multicolumn{2}{|c|}{ Correlation coefficient } \\
\cline { 3 - 4 } & & Cream cheese & Processed cheese \\
\hline & goods in the region & & -0.21 \\
\hline 7 & Retail trade turnover per capita in the region & 0.12 & -0.22 \\
\hline 8 & Share of the male population in the region & -0.18 & 0.56 \\
\hline 9 & Share of the urban population in the region & 0.60 & -0.03 \\
\hline 10 & Per capita income in the region & 0.27 & \\
\hline
\end{tabular}

Source: Compiled by the authors

As can be seen from Table 5, the sale of cream cheese is more influenced by factors related to its availability in stores, in particular, the number of cream cheese sale places per capita in the region and the number of stock keeping units or assortment positions (SKU) in the stores of the region. The share of retail trade turnover has a strong influence on the sales of both types of cheese.

\section{Discussion}

As a result of the analysis, the authors revealed a high role in the consumption of cheese of such a factor as the level of trade development. In turn, the characteristic of trade as an important component of the economic and social way of life of the population is characterized in works by Mayorova (2016). In particular, it is shown that the sale of goods which form a positive image of trade organizations plays an important role in increasing the efficiency of their operation. These goods also include dairy products.

Currently, the population of the Russian Federation is insufficiently provided with dairy products. Thus, the availability of dairy products in one of the typical regions of the Russian Federation is three-quarters of the recommended consumption rates (Oseneva et al., 2017-8). The reasons for this include the low investment attractiveness of dairy cattle, an increase in the share of counterfeit products and a number of other negative factors (Seifullaeva et. al., 2017). However, in other countries, the level of consumption of dairy products, and in particular cheese, plays an important role in the national agriculture and is organically combined with the use of modern microbiological achievements (Eriksson \& Bull, 2017). In this regard, the authors present various ways to solve this problem. For example, the paper by Eliseyeva (Eliseeva \& Makhotina, 2012) analyzes the potential for replacing dairy products of natural animal origin with their plant analogs.

Currently, the level of cheese consumption in the Russian Federation is in the range of 6-7 kg per capita, while the average European level of cheese consumption, according to the research company Nielsen, is $19.2 \mathrm{~kg}$ per capita. Grashuis (2018) shows the potential for differentiating the consumption of cheese as an important direction for the development of farm trade. In particular, it is shown that consumers are willing to pay for the origin of the product. In turn, this confirms the authors' conclusions on the development potential of various types of cheese and a high dependency on the number of stock keeping units or assortment positions (SKU) in the stores. In the works by Dreyer (Dreyer, et al., 2016), the importance of consumption traditions is shown (a case study of Parmesan cheese), which also confirms the high role of the depth of cheese assortment in the stores. Lokhman (2018) addresses the sales of particular types of cheese products using gaming incentives. The paper shows the great potential of the opportunity of influencing consumer preferences.

The results obtained by the authors on the significant value of the number of places of cheese sale confirm the conclusions and, in many respects, coincide with the results of research by Titus (2016), which also shows the high role of product availability in the maximum possible number of stores. Also, the results obtained by the authors in connection with the high influence of the number of cottage cheese sale places are largely interrelated with the research by Mesic (2018), describing the importance of various distribution channels when selling food products. 


\section{ENTREPRENEURSHIP AND SUSTAINABILITY ISSUES}

ISSN 2345-0282 (online) http://jssidoi.org/jesi/ 2019 Volume 7 Number 1 (September) http://doi.org/10.9770/jesi.2019.7.1(44)

In the works by Vargas-Bello-Perez (2014), it has been shown that the main buyer of cheese in the family is a woman (52\%), which confirms the slight negative correlation of sales of cheese obtained by the authors depending on the male population share.

Thus, the results obtained by a number of modern scholars largely confirm the authors' conclusions formulated in this study.

\section{Conclusions}

As a result of the study conducted by the authors in accordance with the goal, an analysis of the dairy products market was carried out taking cream cheese sales as a case study. The result confirms the hypothesis put forward by a number of scholars about the individual preferences in the formation of cheese consumption, which determines the importance of the parameters associated with assortment policy. In particular, such factors as the number of cream cheese sales places per capita in the region and the number of stock keeping units, or assortment positions (SKU) in the stores had significant impact. The level of trade integration, in particular, the development of trade networks in the region, also demonstrates a naturally large role.

As a general conclusion, it is necessary to note the positive trends in the sale of dairy products (in particular, cheese) in the past year, as well as the high potential for its development in the future.

\section{References}

Aleksina, S.B. 2018-19. Scenarios for the development of distribution strategy in the FMCG market under increasing pressure from federal trade networks. Russian Journal of Entrepreneurship, 3: 709-724. https://doi.org/10.18334/rp.19.3.38835

Angelidis, A.S., Georgiadou, S.S., Zafeiropoulou, V. Velonakis, E.N., Papageorgiou, D.K., \& Vatopoulos, A. 2012. A survey of soft cheeses in Greek retail outlets highlights a low prevalence of Listeria spp. Dairy Science \& Technology, 92(2): 189-201. https://doi.org/10.1007/s13594-011-0049-y

Boatto, V., Rossetto, L., Bordignon, P., Arboretti, R., \& Salmaso, L. 2016. Cheese perception in the North American market Empirical evidence for domestic vs imported Parmesan. British Food Journal. 118(7) https://doi.org/10.1108/BFJ-09-2015-0315

Buleca, J., Kováč, V., \& Šubová, N. 2018. Milk production related to price of raw cow's milk in selected European countries. Potravinarstvo Slovak Journal of Food Sciences, 12(1): 798-805. https://doi.org/10.5219/1002

Canfora, C., \& Ottmann, A. 2018. Of ostriches, pyramids, and Swiss cheese risks in safety-critical translations. Translation Spaces (Netherland), 7(2): 167-201. https://doi.org/10.1075/ts.18002.can

Ceccarelli, M. 2017. Milk magic and related topics in Sumerian texts. [Milchzauber und Verwandtes in sumerischen Texten] Fabula, 58(34): 375-382. https://doi.org/10.1515/fabula-2017-0032

De-Magistris, T., \& Lopez-Galan, B. 2016. Consumers' willingness to pay for nutritional claims fighting the obesity epidemic: the case of reduced-fat and low salt cheese in Spain. Public health, 135: 83-90. https://doi.org/10.1016/j.puhe.2016.02.004

Dreyer, H. C., Strandhagen, J. O., Hvolby, H., Romsdal, A., \& Alfnes, E. 2016. Supply chain strategies for speciality foods: A Norwegian case study. Production Planning and Control, 27(11): 878-893. https://doi.org/10.1080/09537287.2016.1156779

Eliseeva, L. G, \& Makhotina, I. A. 2012. Influence of the induced autolysis biotechnology on the biological value of the lupine flour (book chapter). Modern problems in biochemical physics: New Horizons. Nova Science Publishers, Inc. pp. 231-235

Eliseeva, L.G., Makhotina, I.A., Gorozhanin, P.P., \& Yurina, O.V. 2015. Experience in the application of bioassays with planarian in the studies of drinking bottled water safety. Mediterranean Journal of Social Sciences, 6(2S4): 29-32. 


\section{ENTREPRENEURSHIP AND SUSTAINABILITY ISSUES}

ISSN 2345-0282 (online) http://jssidoi.org/jesi/ 2019 Volume 7 Number 1 (September) http://doi.org/10.9770/jesi.2019.7.1(44)

Eriksson, C., \& Bull, J. 2017. Place-making with goats and microbes: The more-than-human geographies of local cheese in Jämtland, Sweden. Journal of Rural Studies, 50: 209-217. https://doi.org/10.1016/i.jrurstud.2017.01.010

Filipovic, J. 2019. Market-Oriented Sustainability of Sjenica Sheep Cheese. Sustainability, 11(3): 834. https://doi.org/10.3390/su11030834

Grashuis, J., \& Magnier, A. 2018. Product differentiation by marketing and processing cooperatives: A choice experiment with cheese and cereal products. Agribusiness, 34(4): 813-830. https://doi.org/10.1002/agr.21551

Honfoga, B. G., N'tandou-Bonzitou, G., Vodouhè, R. S., Bellon, M. R., \& Hounhouigan, J. D. 2018. Assessing the role of market integration in the consumption of traditional foods in benin: A joint price instability coefficient and diet composition approach. Agricultural and Food Economics, 6(1). https://doi.org/10.1186/s40100-018-0097-1

Ito, B., Mukunoki, H., Tomiura, E., \& Wakasugi, R. 2019. Trade policy preferences and cross-regional differences: Evidence from individual-level data of japan. Journal of the Japanese and International Economies, 51: 99-109. https://doi.org/10.1016/j.jjie.2018.12.003

Ivanov, G., \& Mayorova, E. (2014). Business reputation and trade efficiency. Economic Annals-XXI, 1 (1-2): 54-57.

Linn, M. 2019. Making milk with conscious care: Raw milk ontologies and the practices of 'bath milk' producers in Victoria, Australia. Journal of Rural Studies, 65: 135-142. https://doi.org/10.1016/j.jrurstud.2018.10.010

Malaws, B., \& McDonald, M. 2018. Bwrdd marchnata llaeth*: Four milk marketing board creameries in wales. Industrial Archaeology Review, 40(1): 25-38. https://doi.org/10.1080/03090728.2018.1452589

Mayorova, E. 2018. Assessing the Corporate Social Responsibility of Retailers for Compliance with Consumer Expectations. Proceedings of the 32nd International Business Information Management Association Conference, IBIMA 2018 - Vision 2020: Sustainable Economic Development and Application of Innovation Management from Regional expansion to Global Growth, November 15-16, 2018, Seville, Spain, 1899-1904.

Mayorova, E.A., \& Lapitskaya, N.V. 2016. Assessment of customers' perception of social responsibility of trade business. International Journal of Economics and Financial Issues, 6(2): 158-163.

Mesic, Ž., Molnár, A., \& Cerjak, M. (2018). Assessment of traditional food supply chain performance using triadic approach: The role of relationships quality. Supply Chain Management, 23(5): 396-411. https://doi.org/10.1108/SCM-10-2017-0336

Lokhman, N., Karashchuk O. \& Kornilova O. 2018. Analysis of eSports as a commercial activity. Problems and Perspectives in Management, 16(1): 207-213. https://doi.org/10.21511/ppm.16(1).2018.20

Nigri, E.M., de Barros, A.C., Rocha, S.D.F., Romeiro, E. 2014. Assessing environmental impacts using a comparative LCA of industrial and artisanal production processes: "Minas Cheese" case. Food Science and Technology, 34(3): 522-531. https://doi.org/10.1590/1678$\underline{457 X .6356}$

Kornilova, O. \& Karashchuk, O. 2017. Socially responsible business in trade: further development in Ukraine and Russia. Problems and Perspectives in Management, 15(3): 445-452. https://doi.org/10.21511/ppm.15(3-2).2017.12

Oseneva O.V., Shchetilina I.P., \& Borisova V.V. (2017-8). Analysis of the structure of the consumer basket and the purchasing power of the population of the Voronezh region in relation to dairy products. Azimuth of Scientific Research: Economics and Administration, 2(23): $251-253$

Quaranta, G., \& Salvia, R. 2017. Social-based product innovation and governance in the milk sector: The case of carciocacio and innonatura. Driving agribusiness with technology innovations, pp. 293-310. https://doi.org/10.4018/978-1-5225-2107-5.ch015

Sanchez-Macias, D., Moreno-Indias, I., Alvarez, S., Clevelan, M., Castro, N., Arguello, A., \& Fresno, M.D. 2012. Sensory analysis of full-, reduced- and low-fat cheese elaborated with raw goat milk. Journal of Applied Animal Research, 40(2): 124-132, https://doi.org/10.1080/09712119.2011.633880

Santos-Lavalle, R., Flores-Verduzco, J.J., Cervantes-Escoto, F., Salas-Gonzalez, J.M., Sagarnaga-Villegas, L.M. 2018. Opportunities for goat farmers in Guanajuato, Mexico, in the marketing of fine cheese. Revista Mexicana de Ciencias Pecuarias, 9(3): 601-613. https://doi.org/10.22319/rmcp.v9i3.4500 


\section{ENTREPRENEURSHIP AND SUSTAINABILITY ISSUES}

ISSN 2345-0282 (online) http://jssidoi.org/jesi/ 2019 Volume 7 Number 1 (September) http://doi.org/10.9770/jesi.2019.7.1(44)

Seifullaeva, M. E., Shirochenskaya, I. P., Shklyar, T. L., Mkhytaryan, S. V., \& Panasenko, S. V. 2017. Strategy of import substitution at Russian food market. International Journal of Economic Perspectives, 11(3).

Talbot-Walsh, G., Kannar, D., \& Selomulya, C. 2018. A review on technological parameters and recent advances in the fortification of processed cheese. Trends in Food Science and Technology, 81: 193-202. https://doi.org/10.1016/j.tifs.2018.09.023

Titus, R. 2016. Analyzing in-store \& consumer factors in Adoption of Cheese as a Retail Product in Indian Market. International conference on business and economics (ICBE2016), pp. 471-472.

Vargas-Bello-Perez, E., Aguilar, C., Toro-Mujica, P., Vera, R.R., Cerda, M., \& Briones, I. 2014. Characterization of cheese consumers in Santiago Province, Chile. Ciencia e Investigacion Agrarian, 41(3): 327-335. https://doi.org/10.4067/S0718-16202014000300005

Zindy, P., Halawany-Darson, R., \& Hauwuy, A. (2017). Consumers' perception and attitude towards regional "terroir" products: focus on "terroir" cheeses. Inra Productions Animals, 30(3): 229-240.

Leonid Aleksandrovich BRAGIN

ORCID ID: 0000-0002-3468-3212

Svetlana Victorovna PANASENKO

ORCID ID: 0000-0002-7884-6124

Alexander Fedorovich NIKISHIN

ORCID ID: 0000-0003-1545-7970

Svetlana Borisovna ALEKSINA

ORCID ID: 0000-0002-4289-2233

Anastasiya Vladimirovna BOYKOVA

ORCID ID: 0000-0003-0790-614X

Register for an ORCID ID:

https://orcid.org/register

Copyright (C) 2019 by author(s) and VsI Entrepreneurship and Sustainability Center

This work is licensed under the Creative Commons Attribution International License (CC BY).

http://creativecommons.org/licenses/by/4.0/

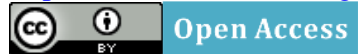

